\title{
Generation of Electricity by Microbial Fuel Cells using Industrial Effluent
}

\author{
Md. Zakir Hossain, Md. Jakir Hossen, M. Mostaqur Rahman, Md. Dewan Mazharul Hasan \\ and Md. Ahasanul Alam
}

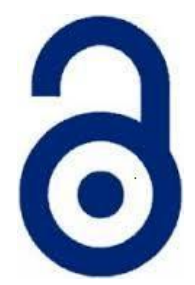

Received: 03 December 2020

Accepted: 29 December 2020

Published: 30 January 2021

Publisher: Deer Hill Publications

(c) 2021 The Author(s)

Creative Commons: CC BY 4.0

\begin{abstract}
A microbial fuel cell (MFC) is a device that converts bio-chemical energy into electrical energy during substrate oxidation with the aid of microorganisms (bacteria). The energy contained in waste water is converted to the electrical power by the action of bacteria. The principle of MFC is to transfer electrons from the microorganisms to electron acceptor at a higher electrochemical potential. An experimental study was performed to find the most efficient industrial waste water that can produce highest and stable electrical power by the MFC and to determine the removal rate of pollutant from the waste water by the MFC. Two MFC, namely one PEM MFC and two PEM FMC, has been fabricated for this study. The three different waste water samples used were Dyeing Waste Water-1 (DWW-1), Dairy Industry Waste Water (DIWN) and Dyeing Waste Water-2 (DWN-2). The highest rate of voltage generation is achieved when the MFC was operated with DWW-1 (1.06 V), DIWW (0.95 V) and DWN-2(0.644 V), respectively. Based on the graph pattern the DWW-1 provided the best record in terms of electrical energy generation.
\end{abstract}

Keywords: Microbial Fuel Cell (MFC), Industrial Waste Water, Proton Exchange Membranes (PEM)

\section{INTRODUCTION}

In globalization era, people faces energy insecurity and climate change due to depletion of non-renewable energy and global warming. In present situation of the world, most of the energy comes from non-renewable energy sources. But the source of non-renewable energy are limited. After certain time non-renewable energy will be finished. So everyday researcher try to find the new sustainable, renewable and alternative sources of energy. There are lot of renewable energy sources found by the researcher. Microbial Fuel Cell is one of them. It's a promising technology to meet increasing energy needs using wastewaters as substrates for producing electricity and also wastewater treatment[1]. MFC does not use commercially due to low power generation and its high cost [2]. Researcher always try to overcome this limitation for development the performance and commercialization of MFCs.

Microbial fuel cell (MFC) is a green energy technology which used for electricity generation, wastewater treatment, bioremediation, biosensors hydrogen production[3] and biological oxygen demand (BOD) sensors [4]. Depend on design, MFC can be classified into two group: single chambered and double chambered. The single chambered MFC contain both cathode and anode in one chamber. On the other hand double chambered MFC contain separate cathode and anode. In double chambered MFC cathode and anode chamber are separate by proton exchange membrane[5]. The function and efficiency of MFC for power production is mainly depend on the following factors nature of carbon source used, fuel cell configuration, nature and type of electrode, mediators present in the cathode chamber, electrolytes used[6], operating temperature[7] and nature of the proton exchange membrane[8].

At present, the power industry faces difficulties ensuring the production of greater volumes of energy to meet the increased demand. Simultaneously, the production of waste and wastewater increases considerably. This means that large amounts of industrial and municipal wastewater may be generated. The traditional design of a wastewater treatment plant consumes a lot of energy to perform efficiently, and this generates considerable costs. In this context, it is clear that it is important to decrease the costs of wastewater treatment. Nowadays, there are different ideas for the use of wastewater as a raw material for other technologies, and there has been fast development in renewable

Hossain, M.Z.', Hossain, M.J. ${ }^{2}$, Rahman, M.M. ${ }^{1}$, Hasan, M.D.M. ${ }^{1}$ and Alam, M.A. ${ }^{1} \bowtie$

'Department of Mechanical Engineering, Dhaka University of Engineering and Technology

Gazipur-1707, Bangladesh

${ }^{2}$ Institute of Energy Engineering, Dhaka University of Engineering and Technology

Gazipur-1707, Bangladesh

E-mail: sumon1314@yahoo.com

Reference: Hossain et al., (2021). Generation of Electricity by Microbial Fuel Cells using Industrial Effluent. International Journal of Engineering Materials and Manufacture, 6(1), 22-33. 
sources of energy using wastewater. A microbial fuel cell (MFC) is device that can produce electricity with wastewater treatment [9]. Energy is expelled from wastewater by anaerobic digestion from different substrate[10].

The high energy requirements of conventional wastewater treatment systems are demanding for an alternative treatment technology. This treatment technology should be cost effective, requiring less energy for its efficient operation, and should generate energy in such a form that would make overall operation of wastewater treatment self-sustainable. Organic matter present in the wastewater can be considered a valuable material acting as a renewable source of energy. The energy available in organic wastewaters can be harvested as electricity by using Microbial Fuel Cell (MFC). In this case to catalyze the conversion of organic matter into direct electricity while accomplishing the biodegradation of organic matter to carbon dioxide as an end product the bacteria can be used. Use of MFC for wastewater treatment has various advantages, such as a high efficiency for energy conversion of the organic matter into electricity, working at lower mesophilic temperatures, and the absence of any toxic products. In addition, wastewaters can be used as substrates in MFC to produce electricity[11] and compensate the cost of treatment. If MFCs are used for wastewater treatment, can provide clean and safe energy for people, apart from effective treatment of the wastewaters with and low noise and emissions.

Although, many researchers have performed extensive studies on the construction and analysis of MFCs in the last twenty years. But, clear information on the construction and analysis of MFCs is still limited and not clarified yet.

\section{MATERIALS AND METHODS}

\subsection{Experimental Setup}

Microbial fuel cell basically contains an anode chamber, a cathode chamber, PEM or salt bridge, external circuit [12] and electrode assembly. Many different configurations are used in MFCs. The most common configuration is a two chamber MFC with " $\mathrm{H}$ " shape, consisting of two bottles connected by a tube with a proton exchange membrane in the middle[13]. The key point to this design is the use of a small membrane separating the two chambers. However, these MFCs typically have a high internal resistance because of the long distance between the two electrodes and the small surface area of the membrane, hence limiting power density output. Two-chamber MFCs are basically use in batch mode and also can run in continuous mode[14]. They are especially suitable for laboratory research, such as examining power production using new substrates, electrode materials, membranes or types of microbial communities that arise during the degradation of specific compounds, or for MFC based sensors. Performance of an MFCs are mainly depend on the following factors configuration of electrode, electrode materials, membranes, mediators and the biocatalysts[15]. The following figures shows the experimental setup for the analysis mentioned:

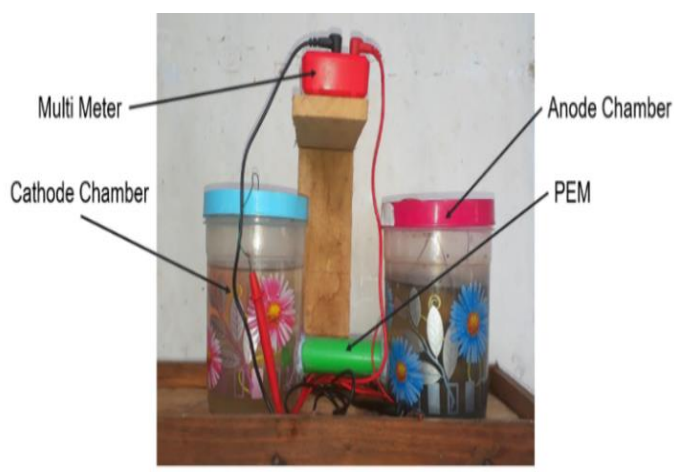

Figure 1: Experimental setup of two chambered MFC with one PEM

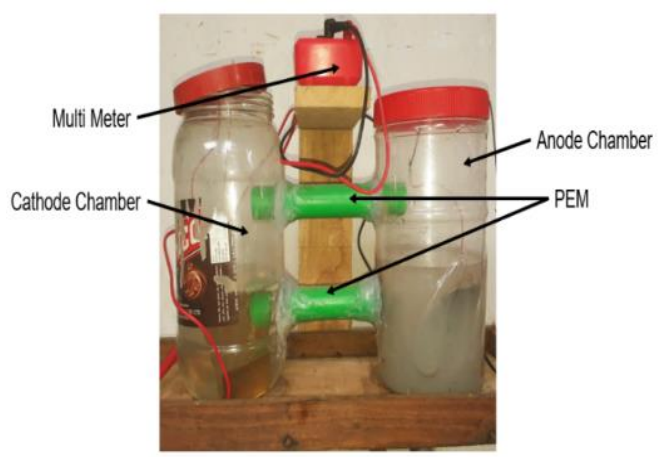

Figure 2: Experimental setup of two chambered MFC with two PEM

\subsection{Electrodes}

Power density of a Microbial Fuel Cell (MFC) mainly depends on the performance of electrodes. So electrode plays a vital role on MFCs. There are different types of electrodes which can be used in MFC. Carbonaceous and metallicbased electrodes are mainly used in MFCs. Among them carbonaceous materials, carbon cloth, carbon brush, carbon rod, carbon mesh, carbon veil, carbon paper, carbon felt, granular activated carbon, granular graphite, carbonized cardboard, graphite plate and reticulated vitreous carbon are commercially available. Metal based materials such as stainless steel plate, stainless steel mesh, stainless steel scrubber, silver sheet, nickel sheet, copper sheet, gold sheet and titanium plate are commercially available. Carbon-based nanomaterial's such as Carbon nanotubes (CNTs), allotropes of carbon and Composite materials such as CNT-polyaniline are used as electrode[16]. As an electrode material carbon nanotube platinum (CNT/Pt) - coated Carbon Paper(CP) are used in dual-chambered MFCs[17]. The following features should have the electrode material i) Electrical conductivity; ii) Resistance to Corrosion; iii) High Mechanical Strength; iv) Developed surface area; v) Biocompatibility; vi) Environmentally friendly and vii) Low cost [18]. Based on these features following electrode materials were used in this study: Copper $(\mathrm{Cu})$, Aluminum ( $\mathrm{Al}), \mathrm{Carbon}(\mathrm{C})$ and Brass. High internal resistance of electrode material effects on output power of MFC. Sustainability and cost of electrode materials are an important issue[19]. 
Table 1: Different types of electrode material with size

\begin{tabular}{ll}
\hline Electrode Material & Cross Section \\
\hline Copper & $13.2 \mathrm{~cm} * 5.5 \mathrm{~cm}$ \\
Aluminium & $13.2 \mathrm{~cm} * 5.5 \mathrm{~cm}$ \\
Brass & $13.2 \mathrm{~cm} * 5.5 \mathrm{~cm}$ \\
Carbon & $15.5 \mathrm{~cm}$ bar with $1 \mathrm{~cm}$ diameter \\
\hline
\end{tabular}

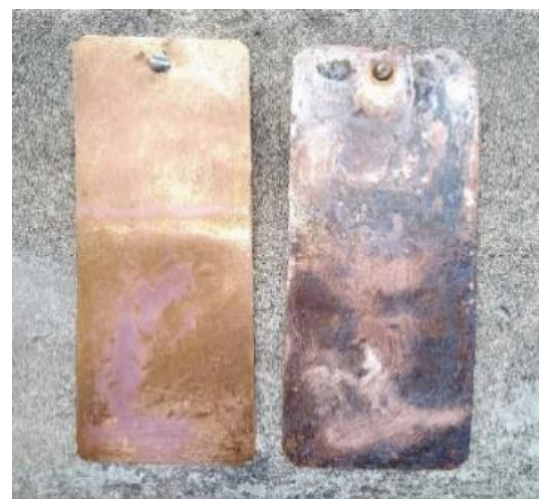

Figure 3: Copper electrode

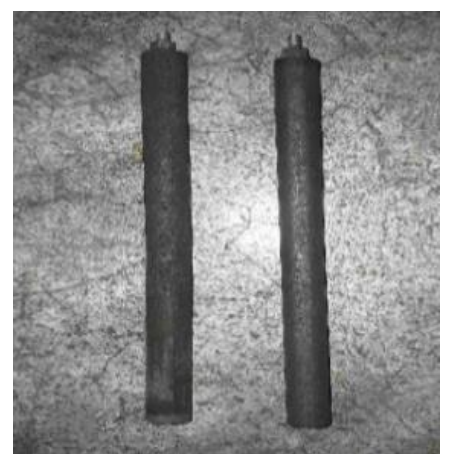

Figure 5: Carbon electrode

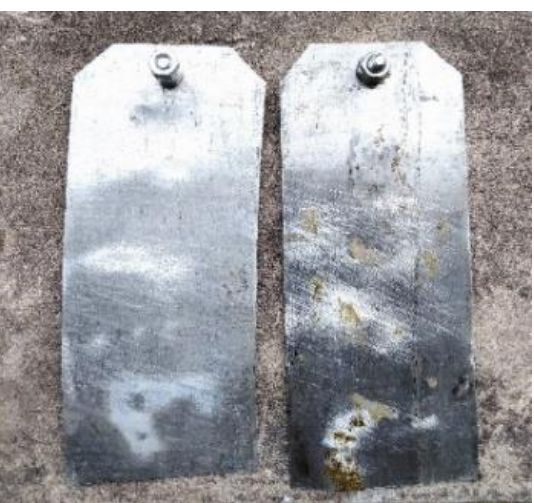

Figure 4: Aluminium electrode

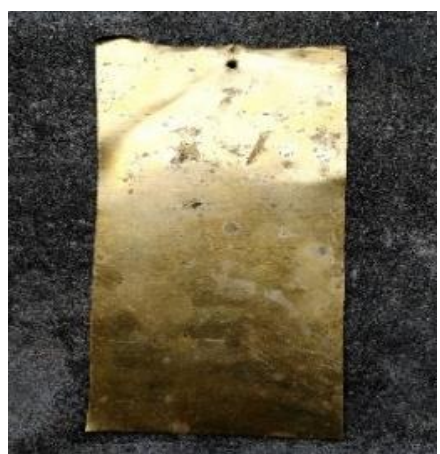

Figure 6: Brass electrode

\subsection{Proton Exchange Membranes (PEMs)}

A proton-exchange membrane (PEM), is a semipermeable membrane which permit to transfer proton from anode chamber to cathode chamber. It's a separator which separate the anode and the cathode. It prevent the mixing of substrate in anode and cathode chambers, especially by effluent, $\mathrm{CO}_{2}$, and oxygen[20]. In MFC Nafion, cellophane, agar composition etc. are usually used as Proton exchange membranes (PEM) [21]. The power density of a MFC also depends on the performance of PEM. If the surface area of electrode is larger than the area of PEM the power output decreases. Logan and Sang identify that power density increases if the area is in the ratio 2 Aanode $=\mathrm{APEM}=2$ Acathode [21]. The experiment was conducted with an agar salt bridge as a PEM. The PEM made with 1 mole of $\mathrm{KCL}$ and $10 \%$ of agar solution. One another salt bridge used as a PEM which made with 1 mole of $\mathrm{NaCl}$ and $10 \%$ of agar solution. The diameter and length of the salt bridge is $2 \mathrm{~cm}$ and $15 \mathrm{~cm}$ respectively.

\subsection{Method}

The MFC reactor (Fig. 1 \& Fig. 2) was designed and fabricated from acrylic material. It consisted of two chambers (1 liter each) for the anode and cathode compartment, which were separated by a PEM $(D=2 \mathrm{~cm})$. The cathode chamber of MFC was filled with normal water as a catholyte. The anode chamber was filled with the wastewater samples. The cathode and anode electrodes that were used composed of different metallic electrodes mentioned above. The cathode and the anode are connected with an external circuit by using connecting wires. Both sides of the anodic chamber and cathodic chamber are capped tightly to avoid the addition of unwanted material throughout the entire MFC process (until the voltage became zero or stable as long as 50 hours). A digital multi meter is connected to a resistor in a parallel circuit to measure and record the open electric voltage produced by the electric flow in the MFC throughout the process. Chemical Oxygen Demand (COD) and Total Kjedahl Nitrogen (TKN) were measured before and after the MFC operation to determine the rate of carbon and nitrogen removal in wastewater. The $\mathrm{pH}$ value of the wastewater is observed to identify suitable $\mathrm{pH}$ conditions for bacterial growth during MFC operation. The MFC operation is conducted by testing on three types of wastewater samples: Dyeing waste water- 1, Dairy food waste water and Dyeing waste water-2. 


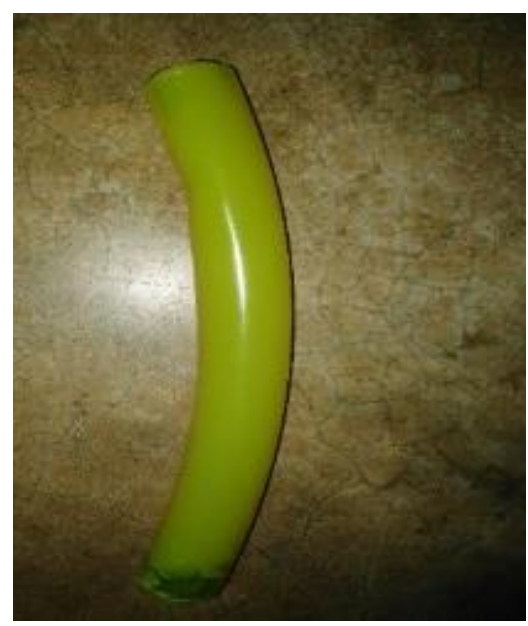

Figure 7: Side view of Salt bridge made with $\mathrm{KCL}, \mathrm{NaCl}$ and agar

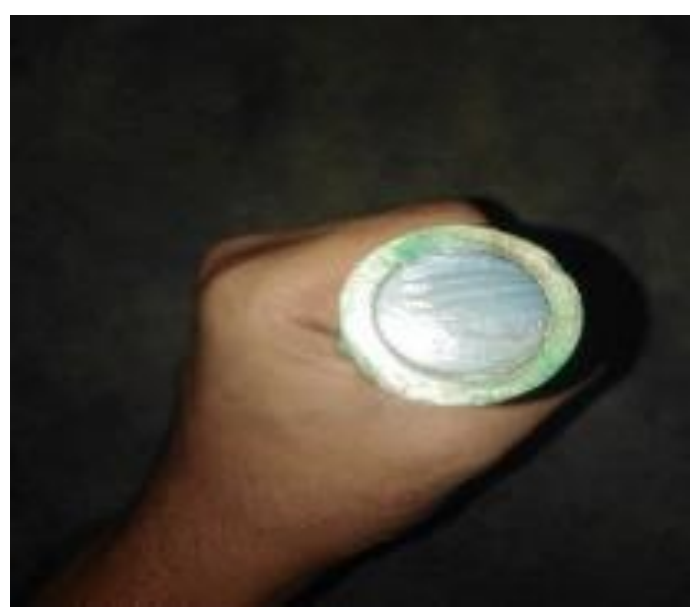

Figure 8: Cross Sectional view of Salt bridge made with $\mathrm{KCL}, \mathrm{NaCl}$ and agar

\subsection{Two Salt bridge MFC}

To increase the proton exchange area through the PEM, two salt bridges were made from the $\mathrm{KCL}$ and agar and attached to the set up as shown in Fig. 2. The other processes were same followed by single PEM MFC. During this process copper electrode were used in both anode and cathode chamber.

\section{RESULTS \& DISCUSSION}

\subsection{Dyeing Waste water-1 (DWN-1)}

As large surface area increases the proton exchange rate, so the observation was starts with making two salt bridges with two chambered MFC. According to Fig. 9 the open-circuit voltage at the beginning of the study was recorded as $0.52 \mathrm{~V}$ and maximum voltage was found as $0.559 \mathrm{~V}$. Based on the pattern of the graph shown, the voltage generation increased from the beginning for a small time because of the formation of the biofilm of microorganisms of the waste water and then decreased gradually without increasing until the last observable voltage found. The voltage decreases because of the microorganisms start to compete each other to obtain their foods from the organic matter and nutrients in the waste water [22]. In this case copper electrode were used in both anode and cathode side. $0.2 \mathrm{~mA}$ stable current was found by one PEM MFC.

When using the same electrodes (copper) for one PEM different results of voltage were found with respect to time. The voltages found using one PEM were found small than that found by two PEM MFC. In this case starting voltage was found as $0.291 \mathrm{~V}$ and maximum voltage was $0.35 \mathrm{~V}$. The graph pattern showed in Fig. 10 is almost similar to Fig. 9 including low voltages than previous. Similarly, $0.2 \mathrm{~mA}$ stable current was found by one PEM MFC.

By using aluminium as anode and brass as cathode of similar size of copper electrode observable change was found in voltage and current. The Fig. 11 shows the graphical representation of time and voltage of DWN-1 when using one PEM. In this case the voltages were observed till 85 hours. The starting voltage, maximum voltage was found as $1.017 \mathrm{~V}$ and $1.06 \mathrm{~V}$ respectively. The current was found as $0.7 \mathrm{~mA}$ (stable).

Table 2: Electricity production from Dyeing waste water-1 (Two salt bridges) with respect to time

\begin{tabular}{cccccc}
\hline $\begin{array}{c}\text { Time } \\
\text { (Hours) }\end{array}$ & $\begin{array}{c}\text { Electricity } \\
\text { production }(V)\end{array}$ & $\begin{array}{c}\text { Time } \\
\text { (Hours) }\end{array}$ & $\begin{array}{c}\text { Electricity } \\
\text { production }(V)\end{array}$ & $\begin{array}{c}\text { Time } \\
\text { (Hours) }\end{array}$ & $\begin{array}{c}\text { Electricity } \\
\text { production }(V)\end{array}$ \\
\hline 0 & 0.52 & 9 & 0.419 & 18 & 0.165 \\
1 & $0.559(\mathrm{Max})$ & 10 & 0.35 & 19 & 0.1 \\
2 & 0.545 & 11 & 0.283 & 20 & 0.085 \\
3 & 0.53 & 12 & 0.265 & 21 & 0.05 \\
4 & 0.52 & 13 & 0.263 & 22 & 0.02 \\
5 & 0.511 & 14 & 0.25 & 23 & 0.005 \\
6 & 0.5 & 15 & 0.22 & 24 & 0 \\
7 & 0.493 & 16 & 0.19 & & \\
8 & 0.433 & 17 & 0.175 & & \\
\hline
\end{tabular}




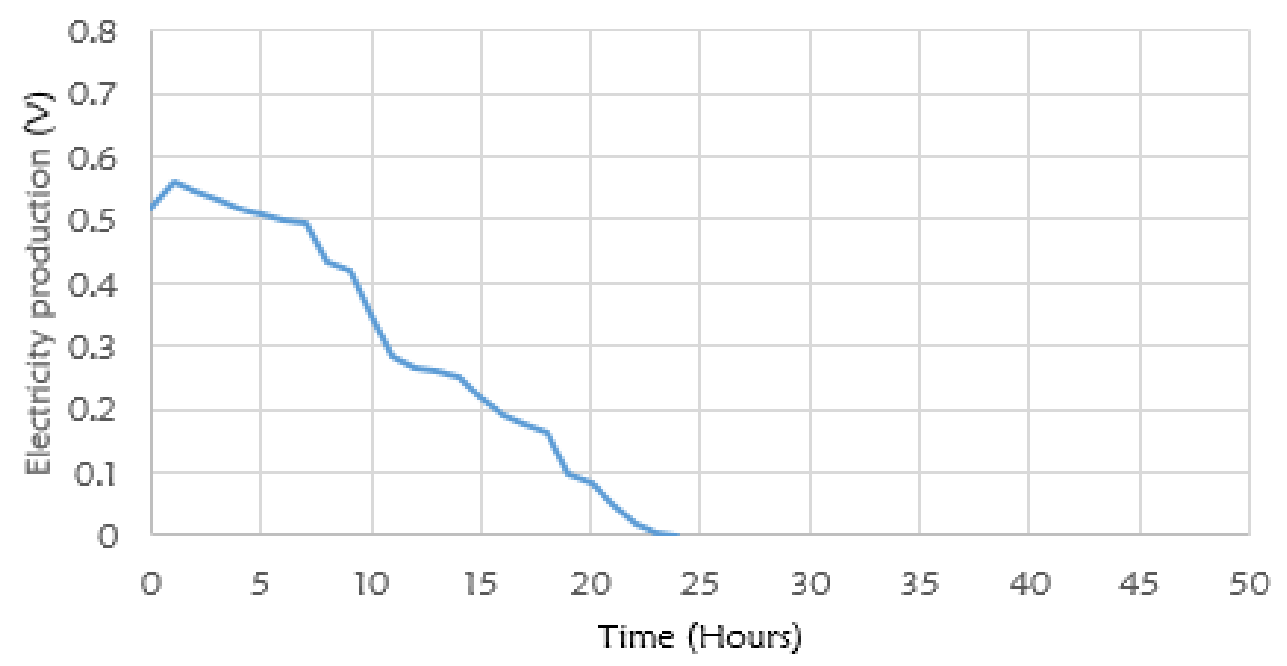

Figure 9: Electricity production versus time for Dyeing waste water-1 (Two salt bridges)

Table 3: Electricity production from Dyeing waste water-1 (One salt bridges) with respect to time

\begin{tabular}{cccccc}
\hline $\begin{array}{c}\text { Time } \\
\text { (Hours) }\end{array}$ & $\begin{array}{c}\text { Electricity } \\
\text { production }(V)\end{array}$ & $\begin{array}{c}\text { Time } \\
\text { (Hours) }\end{array}$ & $\begin{array}{c}\text { Electricity } \\
\text { production }(V)\end{array}$ & $\begin{array}{c}\text { Time } \\
\text { (Hours) }\end{array}$ & $\begin{array}{c}\text { Electricity } \\
\text { production }(V)\end{array}$ \\
\hline 0 & 0.291 & 9 & 0.256 & 18 & 0.158 \\
1 & $0.35($ Max) & 10 & 0.24 & 19 & 0.144 \\
2 & 0.32 & 11 & 0.231 & 20 & 0.129 \\
3 & 0.31 & 12 & 0.223 & 21 & 0.1 \\
4 & 0.305 & 13 & 0.22 & 22 & 0.07 \\
5 & 0.3 & 14 & 0.209 & 23 & 0.065 \\
6 & 0.28 & 15 & 0.2 & 24 & 0.003 \\
7 & 0.275 & 16 & 0.18 & & \\
8 & 0.26 & 17 & 0.165 & & \\
\hline
\end{tabular}

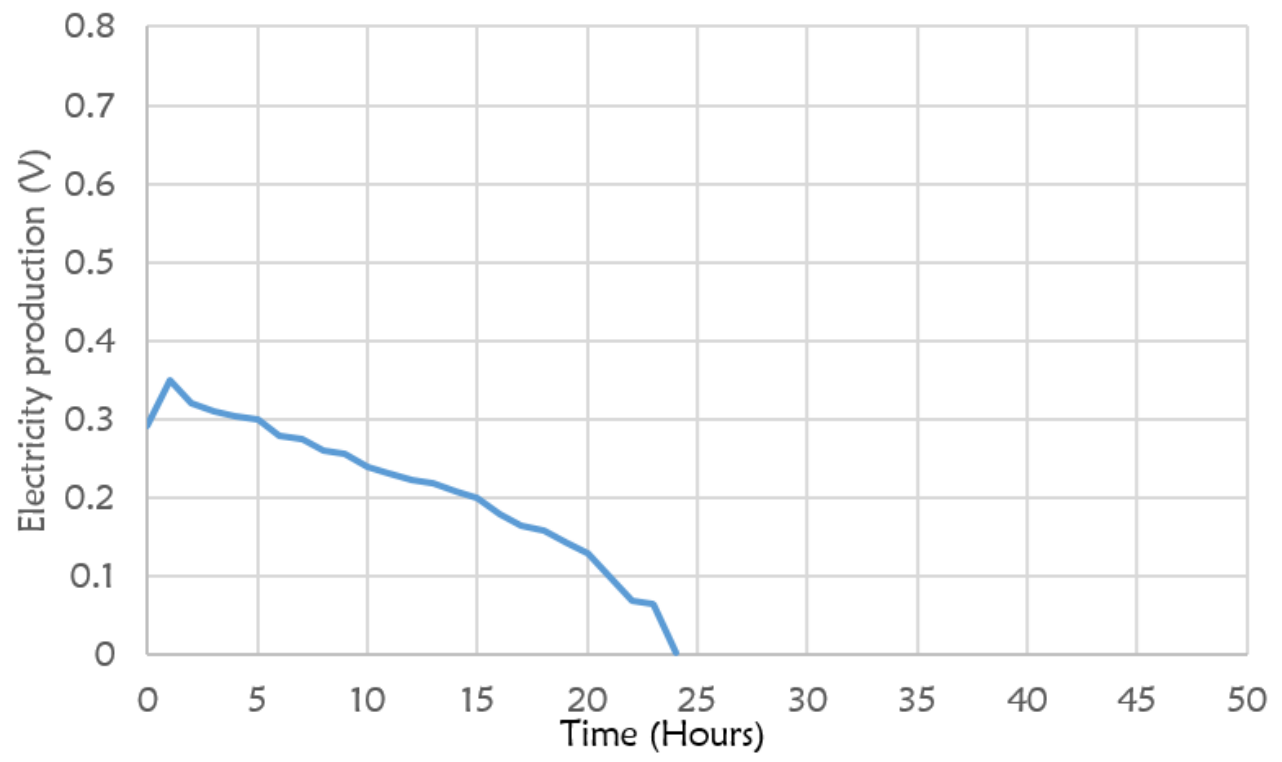

Figure 10: Electricity production versus time for Dyeing waste water-1 (One salt bridge) 
Table 4: Electricity production from Dyeing waste water-1 with respect to time (Aluminium anode, Brass cathode)

\begin{tabular}{cccccccc}
\hline $\begin{array}{c}\text { Time } \\
\text { (Hours) }\end{array}$ & $\begin{array}{c}\text { Electricity } \\
\text { production }(\mathrm{V})\end{array}$ & $\begin{array}{c}\text { Time } \\
\text { (Hours) }\end{array}$ & $\begin{array}{c}\text { Electricity } \\
\text { production }(\mathrm{V})\end{array}$ & $\begin{array}{c}\text { Time } \\
\text { (Hours) }\end{array}$ & $\begin{array}{c}\text { Electricity } \\
\text { production }(\mathrm{V})\end{array}$ & $\begin{array}{c}\text { Time } \\
\text { (Hours) }\end{array}$ & $\begin{array}{c}\text { Electricity } \\
\text { production }(\mathrm{V})\end{array}$ \\
\hline 0 & 1.017 & 22 & 1.028 & 44 & 0.993 & 66 & 0.956 \\
1 & 1.06(Max.) & 23 & 1.024 & 45 & 0.99 & 67 & 0.956 \\
2 & 1.058 & 24 & 1.022 & 46 & 0.99 & 68 & 0.955 \\
3 & 1.055 & 25 & 1.02 & 47 & 0.988 & 69 & 0.954 \\
4 & 1.05 & 26 & 1.018 & 48 & 0.986 & 70 & 0.954 \\
5 & 1.047 & 27 & 1.017 & 49 & 0.984 & 71 & 0.953 \\
6 & 1.045 & 28 & 1.016 & 50 & 0.976 & 72 & 0.953 \\
7 & 1.045 & 29 & 1.0012 & 51 & 0.973 & 73 & 0.952 \\
8 & 1.042 & 30 & 1.009 & 52 & 0.97 & 74 & 0.952 \\
9 & 1.04 & 31 & 1.003 & 53 & 0.971 & 75 & 0.951 \\
10 & 1.04 & 32 & 1.003 & 54 & 0.971 & 76 & 0.951 \\
11 & 1.038 & 33 & 1.003 & 55 & 0.972 & 77 & 0.951 \\
12 & 1.036 & 34 & 1.002 & 56 & 0.972 & 78 & 0.951 \\
13 & 1.035 & 35 & 1.002 & 57 & 0.972 & 79 & 0.951 \\
14 & 1.029 & 36 & 1.001 & 58 & 0.972 & 80 & 0.949 \\
15 & 1.027 & 37 & 1.001 & 59 & 0.97 & 81 & 0.948 \\
16 & 1.025 & 38 & 1.001 & 60 & 0.967 & 82 & 0.948 \\
17 & 1.023 & 39 & 0.999 & 61 & 0.965 & 83 & 0.948 \\
18 & 1.039 & 40 & 0.999 & 62 & 0.963 & 84 & 0.948 \\
19 & 1.032 & 41 & 0.999 & 63 & 0.961 & 85 & 0.948 \\
20 & 1.028 & 42 & 0.995 & 64 & 0.959 & & \\
21 & 1.028 & 43 & 0.993 & 65 & 0.957 & & \\
\hline
\end{tabular}

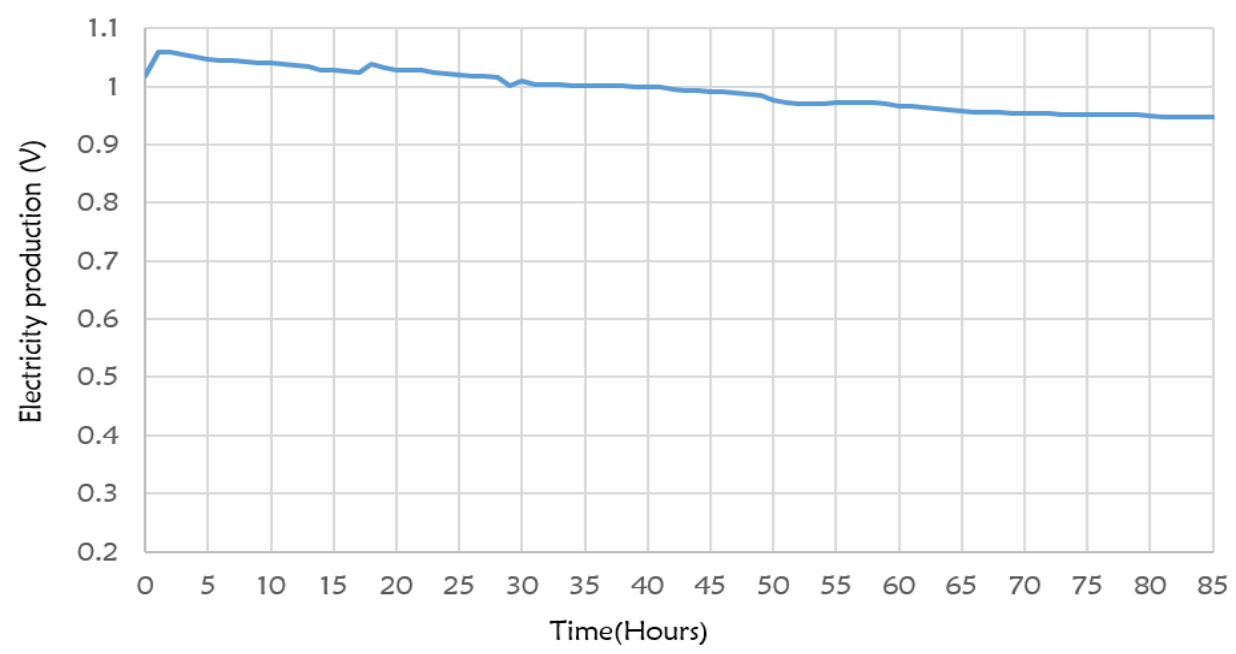

Figure 11: Electricity production versus time for Dyeing waste water-1

\subsection{Dairy Industry Waste Water (DIWN)}

Based on Fig. 12 the initial voltage recorded by MFC that run with the DIWW is $0.27 \mathrm{~V}$ and the maximum voltage is found as $0.716 \mathrm{~V}$. The voltage data was observed for 50 hours. The rate of electric voltage produced experiences a rapid increase for first five hours then decreased slowly for next ten hours. After that the voltages increased gradually and stable for last ten hours. The factor that can be explain that to the sudden drops in voltage is the thickness of biofilm on the electrode surface. The biofilm is the film that produced by microorganisms. The maximum voltage can be obtained whenever this thickness is at moderated condition; not thick or thin. This simultaneous increase and decrease in the electric voltage reading is predicted to continue until all the microorganisms in the waste water are dead and no electric voltage can be generated at the end. The current was found by the MFC was $0.6 \mathrm{~mA}$.

Based on Fig. 13 Aluminium was used as anode, Brass was used as cathode and the voltage reading was taken for 85 hours. With an observable change in voltage the initial voltage was found as $0.85 \mathrm{~V}$ and maximum voltage was found as $0.95 \mathrm{~V}$ (which was found initially). The graph pattern shows more fluctuations in voltage with time within a small range of voltage. Finally, at the last hours the voltage found stable in $0.8 \mathrm{~V}$. This fluctuation of voltage occurred due to condition of biofilm thickness that explained above. 
Table 5: Electricity production from Dairy Industry waste water (One salt bridges) with respect to time

\begin{tabular}{cccccccc}
$\begin{array}{c}\text { Time } \\
\text { (Hours) }\end{array}$ & $\begin{array}{c}\text { Electricity } \\
\text { production }(\mathrm{V})\end{array}$ & $\begin{array}{c}\text { Time } \\
\text { (Hours) }\end{array}$ & $\begin{array}{c}\text { Electricity } \\
\text { production }(\mathrm{V})\end{array}$ & $\begin{array}{c}\text { Time } \\
\text { (Hours) }\end{array}$ & $\begin{array}{c}\text { Electricity } \\
\text { production }(\mathrm{V})\end{array}$ & $\begin{array}{c}\text { Time } \\
\text { (Hours) }\end{array}$ & $\begin{array}{c}\text { Electricity } \\
\text { production }(\mathrm{V})\end{array}$ \\
\hline 0 & 0.27 & 13 & 0.58 & 26 & 0.602 & 39 & 0.705 \\
1 & 0.42 & 14 & 0.56 & 27 & 0.604 & 40 & 0.71 \\
2 & 0.394 & 15 & 0.546 & 28 & 0.606 & 41 & 0.715 \\
3 & 0.59 & 16 & 0.546 & 29 & 0.608 & 42 & 0.714 \\
4 & 0.617 & 17 & 0.548 & 30 & 0.608 & 43 & 0.715 \\
5 & 0.646 & 18 & 0.549 & 31 & 0.609 & 44 & 0.715 \\
6 & 0.666 & 19 & 0.57 & 32 & 0.611 & 45 & $0.716(\mathrm{Max})$ \\
7 & 0.666 & 20 & 0.572 & 33 & 0.628 & 46 & 0.716 \\
8 & 0.665 & 21 & 0.574 & 34 & 0.64 & 47 & 0.716 \\
9 & 0.666 & 22 & 0.576 & 35 & 0.66 & 48 & 0.715 \\
10 & 0.65 & 23 & 0.6 & 36 & 0.67 & 49 & 0.715 \\
11 & 0.62 & 24 & 0.604 & 37 & 0.68 & 50 & 0.716 \\
12 & 0.6 & 25 & 0.605 & 38 & 0.7 & & \\
\hline
\end{tabular}

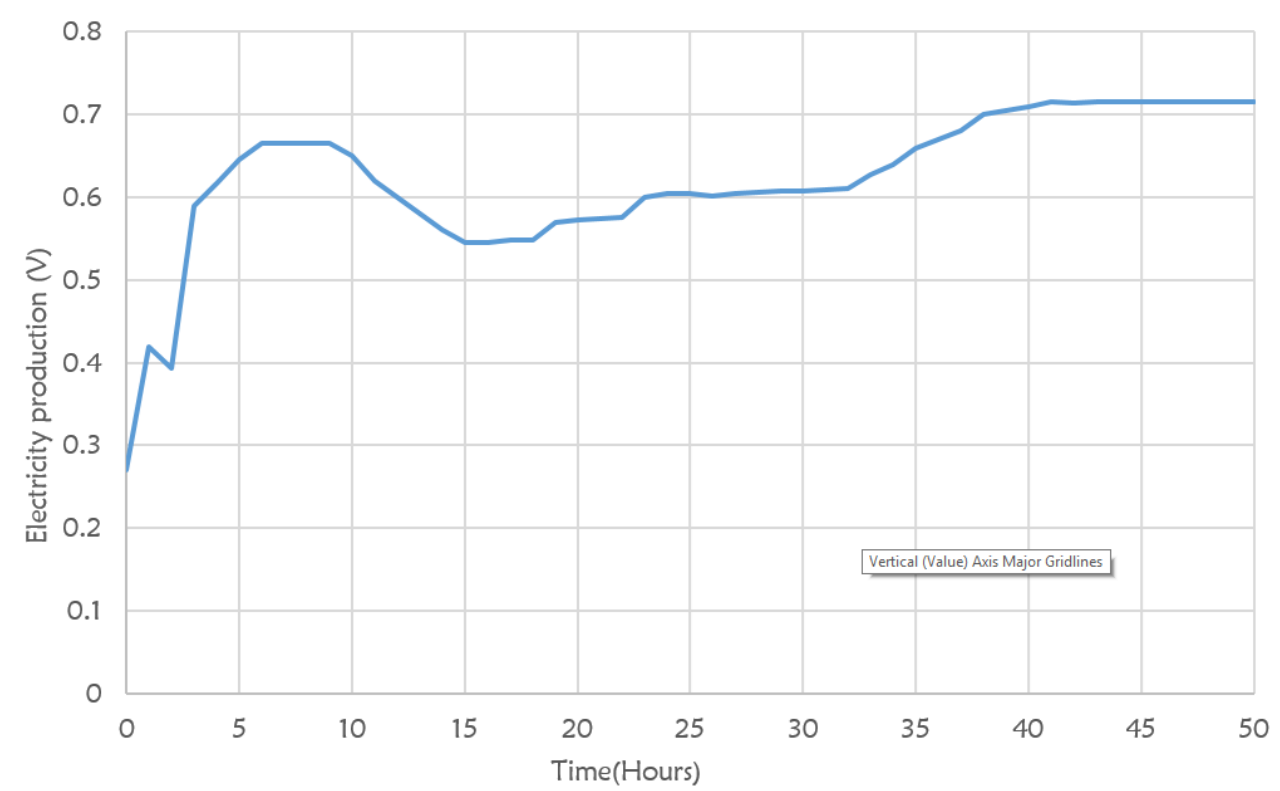

Figure 12: Electricity production versus time for Dairy Industry waste water (One salt bridge)

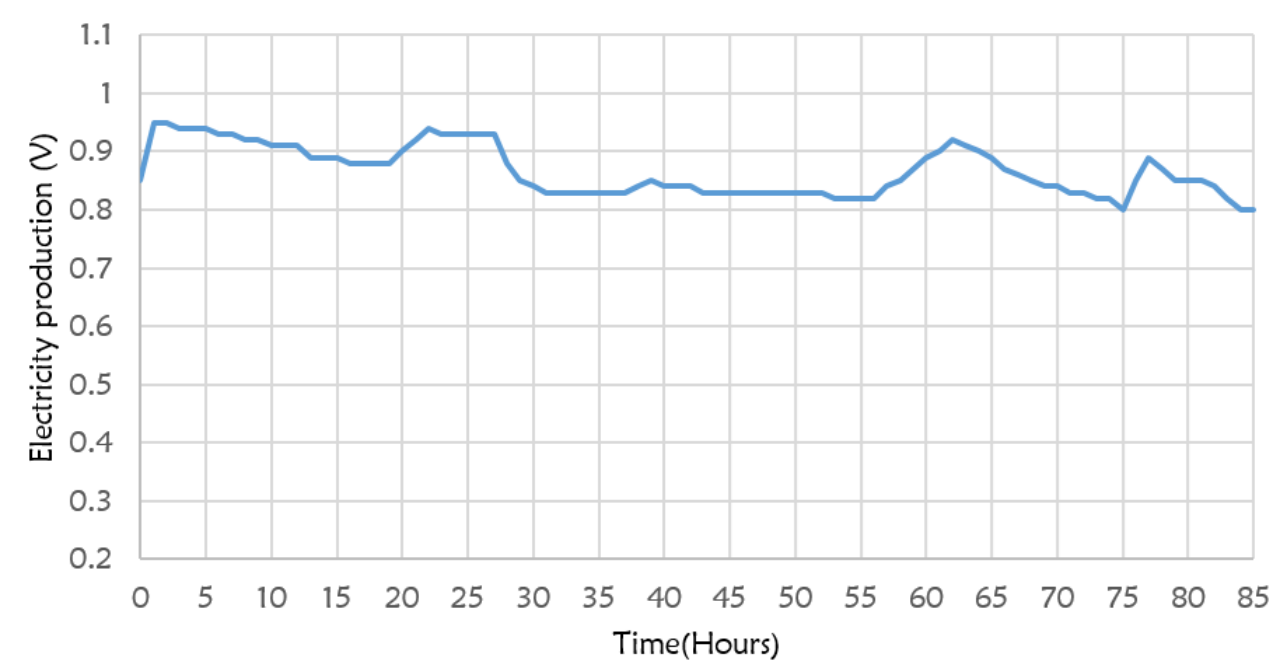

Figure 13: Electricity production versus time for Dairy industry waste water 
Table 6: Electricity production from Dairy Industry wastewater with respect to time (Aluminium anode, Brass cathode)

\begin{tabular}{|c|c|c|c|c|c|c|c|}
\hline $\begin{array}{c}\text { Time } \\
\text { (Hours) }\end{array}$ & $\begin{array}{c}\text { Electricity } \\
\text { production }(\mathrm{V})\end{array}$ & $\begin{array}{c}\text { Time } \\
\text { (Hours) }\end{array}$ & $\begin{array}{c}\text { Electricity } \\
\text { production }(V)\end{array}$ & $\begin{array}{c}\text { Time } \\
\text { (Hours) }\end{array}$ & $\begin{array}{c}\text { Electricity } \\
\text { production }(\mathrm{V})\end{array}$ & $\begin{array}{c}\text { Time } \\
\text { (Hours) }\end{array}$ & $\begin{array}{c}\text { Electricity } \\
\text { production }(\mathrm{V})\end{array}$ \\
\hline 0 & 0.85 & 22 & 0.94 & 44 & 0.83 & 66 & 0.87 \\
\hline 1 & 0.95(Max.) & 23 & 0.93 & 45 & 0.83 & 67 & 0.86 \\
\hline 2 & 0.95 & 24 & 0.93 & 46 & 0.83 & 68 & 0.85 \\
\hline 3 & 0.94 & 25 & 0.93 & 47 & 0.83 & 69 & 0.84 \\
\hline 4 & 0.94 & 26 & 0.93 & 48 & 0.83 & 70 & 0.84 \\
\hline 5 & 0.94 & 27 & 0.93 & 49 & 0.83 & 71 & 0.83 \\
\hline 6 & 0.93 & 28 & 0.88 & 50 & 0.83 & 72 & 0.83 \\
\hline 7 & 0.93 & 29 & 0.85 & 51 & 0.83 & 73 & 0.82 \\
\hline 8 & 0.92 & 30 & 0.84 & 52 & 0.83 & 74 & 0.82 \\
\hline 9 & 0.92 & 31 & 0.83 & 53 & 0.82 & 75 & 0.8 \\
\hline 10 & 0.91 & 32 & 0.83 & 54 & 0.82 & 76 & 0.85 \\
\hline 11 & 0.91 & 33 & 0.83 & 55 & 0.82 & 77 & 0.89 \\
\hline 12 & 0.91 & 34 & 0.83 & 56 & 0.82 & 78 & 0.87 \\
\hline 13 & 0.89 & 35 & 0.83 & 57 & 0.84 & 79 & 0.85 \\
\hline 14 & 0.89 & 36 & 0.83 & 58 & 0.85 & 80 & 0.85 \\
\hline 15 & 0.89 & 37 & 0.83 & 59 & 0.87 & 81 & 0.85 \\
\hline 16 & 0.88 & 38 & 0.84 & 60 & 0.89 & 82 & 0.84 \\
\hline 17 & 0.88 & 39 & 0.85 & 61 & 0.9 & 83 & 0.82 \\
\hline 18 & 0.88 & 40 & 0.84 & 62 & 0.92 & 84 & 0.8 \\
\hline 19 & 0.88 & 41 & 0.84 & 63 & 0.91 & 85 & 0.8 \\
\hline 20 & 0.9 & 42 & 0.84 & 64 & 0.90 & & \\
\hline 21 & 0.92 & 43 & 0.83 & 65 & 0.89 & & \\
\hline
\end{tabular}

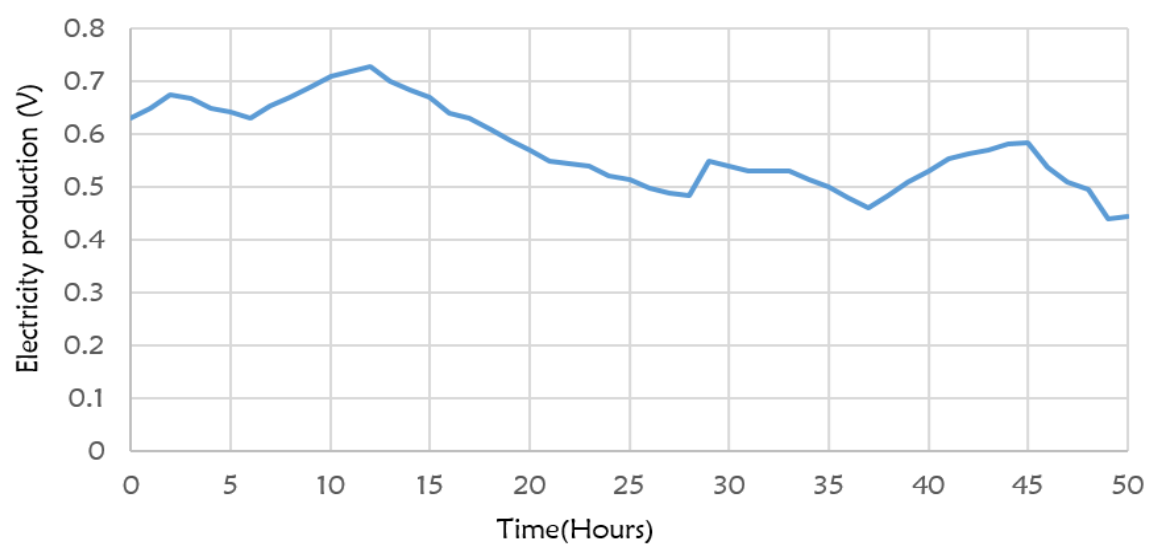

Figure 14: Electricity production versus time for Dyeing waste water-2 (One salt bridge)

\subsection{Dyeing Waste Water-2 (DWW-2)}

Referring to Fig. 14 the voltage produced by the MFC when using one salt bridge and copper electrode in both anode and cathode side is higher than the voltage produced by DWN-1. The initial and maximum voltage were found as $0.63 \mathrm{~V}$ and $0.729 \mathrm{~V}$ respectively. The rate of current was found as $0.2 \mathrm{~mA}$ (stable). From the experimental values collected it seems that there is an observable fluctuation in voltage rate. Initially the voltage was increased for a small time and then decreased also for a small time. Again, the voltage increased from six to twelve hour. After that the voltage further decreased for sixteen hours. These fluctuations occurred due to biofilm formation on the anode electrode for microorganisms.

Again, referring to Fig. 15 the rate of voltage produced is less than the Fig. 14 but the voltage is stable enough. In this case copper was used as anode and brass was used as cathode and data observed for 85 hours. The initial voltage is $0.487 \mathrm{~V}$ and the maximum voltage is $0.644 \mathrm{~V}$. $0.6 \mathrm{~mA}$ stable current was found by the MFC. 
Table 7: Electricity production from Dyeing waste water-2 (One salt bridges) with respect to time

\begin{tabular}{cccccccc}
\hline $\begin{array}{c}\text { Time } \\
\text { (Hours) }\end{array}$ & $\begin{array}{c}\text { Electricity } \\
\text { production }(V)\end{array}$ & $\begin{array}{c}\text { Time } \\
\text { (Hours) }\end{array}$ & $\begin{array}{c}\text { Electricity } \\
\text { production }(V)\end{array}$ & $\begin{array}{c}\text { Time } \\
\text { (Hours) }\end{array}$ & $\begin{array}{c}\text { Electricity } \\
\text { production }(V)\end{array}$ & $\begin{array}{c}\text { Time } \\
\text { (Hours) }\end{array}$ & $\begin{array}{c}\text { Electricity } \\
\text { production }(V)\end{array}$ \\
\hline 0 & 0.63 & 13 & 0.7 & 26 & 0.499 & 39 & 0.51 \\
1 & 0.65 & 14 & 0.684 & 27 & 0.488 & 40 & 0.53 \\
2 & 0.675 & 15 & 0.67 & 28 & 0.483 & 41 & 0.555 \\
3 & 0.668 & 16 & 0.64 & 29 & 0.55 & 42 & 0.563 \\
4 & 0.65 & 17 & 0.63 & 30 & 0.54 & 43 & 0.57 \\
5 & 0.643 & 18 & 0.61 & 31 & 0.53 & 44 & 0.583 \\
6 & 0.631 & 19 & 0.59 & 32 & 0.53 & 45 & 0.585 \\
7 & 0.655 & 20 & 0.57 & 33 & 0.53 & 46 & 0.537 \\
8 & 0.67 & 21 & 0.55 & 34 & 0.515 & 47 & 0.51 \\
9 & 0.69 & 22 & 0.544 & 35 & 0.5 & 48 & 0.495 \\
10 & 0.71 & 23 & 0.539 & 36 & 0.48 & 49 & 0.44 \\
11 & 0.72 & 24 & 0.521 & 37 & 0.46 & 50 & 0.445 \\
12 & 0.729 (Max.) & 25 & 0.515 & 38 & 0.485 & & \\
\hline
\end{tabular}

Table 8: Electricity production from Dyeing waste water-2 with respect to time (Aluminium anode, Brass cathode)

\begin{tabular}{cccccccc}
\hline $\begin{array}{c}\text { Time } \\
\text { (Hours) }\end{array}$ & $\begin{array}{c}\text { Electricity } \\
\text { production }(\mathrm{V})\end{array}$ & $\begin{array}{c}\text { Time } \\
\text { (Hours) }\end{array}$ & $\begin{array}{c}\text { Electricity } \\
\text { production }(\mathrm{V})\end{array}$ & $\begin{array}{c}\text { Time } \\
\text { (Hours) }\end{array}$ & $\begin{array}{c}\text { Electricity } \\
\text { production }(V)\end{array}$ & $\begin{array}{c}\text { Time } \\
\text { (Hours) }\end{array}$ & $\begin{array}{c}\text { Electricity } \\
\text { production }(V)\end{array}$ \\
\hline 0 & 0.487 & 22 & 0.612 & 44 & 0.595 & 66 & 0.598 \\
1 & 0.546 & 23 & 0.61 & 45 & 0.594 & 67 & 0.598 \\
2 & 0.546 & 24 & 0.609 & 46 & 0.594 & 68 & 0.598 \\
3 & 0.545 & 25 & 0.608 & 47 & 0.594 & 69 & 0.599 \\
4 & 0.546 & 26 & 0.604 & 48 & 0.594 & 70 & 0.599 \\
5 & 0.548 & 27 & 0.602 & 49 & 0.593 & 71 & 0.605 \\
6 & 0.555 & 28 & 0.6 & 50 & 0.591 & 72 & 0.605 \\
7 & 0.561 & 29 & 0.597 & 51 & 0.592 & 73 & 0.606 \\
8 & 0.565 & 30 & 0.598 & 52 & 0.593 & 74 & 0.606 \\
9 & 0.573 & 31 & 0.598 & 53 & 0.593 & 75 & 0.607 \\
10 & 0.579 & 32 & 0.598 & 54 & 0.594 & 76 & 0.608 \\
11 & 0.585 & 33 & 0.597 & 55 & 0.594 & 77 & 0.609 \\
12 & 0.587 & 34 & 0.597 & 56 & 0.594 & 78 & 0.61 \\
13 & 0.61 & 35 & 0.596 & 57 & 0.595 & 79 & 0.61 \\
14 & 0.626 & 36 & 0.595 & 58 & 0.595 & 80 & 0.61 \\
15 & 0.631 & 37 & 0.595 & 59 & 0.595 & 81 & 0.61 \\
16 & 0.639 & 38 & 0.595 & 60 & 0.595 & 82 & 0.61 \\
17 & $0.644(\max )$. & 39 & 0.596 & 61 & 0.595 & 83 & 0.61 \\
18 & 0.62 & 40 & 0.595 & 62 & 0.596 & 84 & 0.62 \\
19 & 0.602 & 41 & 0.595 & 63 & 0.596 & 85 & 0.62 \\
20 & 0.604 & 42 & 0.595 & 64 & 0.596 & & \\
21 & 0.607 & 43 & 0.595 & 65 & 0.597 & & \\
\hline
\end{tabular}

3.4 Comparison between Three Waste Water Samples

Fig. 16 shows the Comparison between the open circuit voltages when using DWN-1, DIWW and DWN-2. All of the graphs are plotted in same scale to make a comparison between them. For the DWN-1 the range of electric voltage produced is 0.291 to $0.00 .3 \mathrm{~V}$, for DIWNW the range is 0.27 to $0.716 \mathrm{~V}$ and for DWN-2 the range is 0.63 to $0.445 \mathrm{~V}$. The maximum voltage produced by the MFC is $0.729 \mathrm{~V}$ by using DWW-2. The different in voltage values is due to the presence of different microorganisms in waste waters. By observing the graph pattern, it can be concluded that the voltage produced by DIWW is more consistent than DWN-1 and DWN-2 on the basis of same electrode area, same quantity of waste water and one PEM.

Also the Fig. 17 shows the comparison between these three waste waters when aluminium used as anode and brass used as cathode for DWN-1 and DIWNW and copper as anode and brass as cathode for DWN-2. The data was 
observed for 85 hours for three waste water samples. Brass is the best conductor of electron and can accumulate proton more efficiently than copper, aluminium and carbon. That is why the more stable voltage produced in the second case. According to Fig. 17 the maximum voltage is $1.06 \mathrm{~V}$ and the ranges are for DWN-1, 1.017 to $0.948 \mathrm{~V}$, for DIWN, 0.85 to $0.8 \mathrm{~V}$, and for DWN-2, 0.487 to $0.62 \mathrm{~V}$. In the case of DWN-2 the voltage produced is less than others because of copper was used as anode. Though copper is a good conductor but it is easily effected by bacteria while aluminium doesn't. By observing the graph pattern, it can be concluded that DWW-1 gives the most consistent voltage and also maximum voltage.

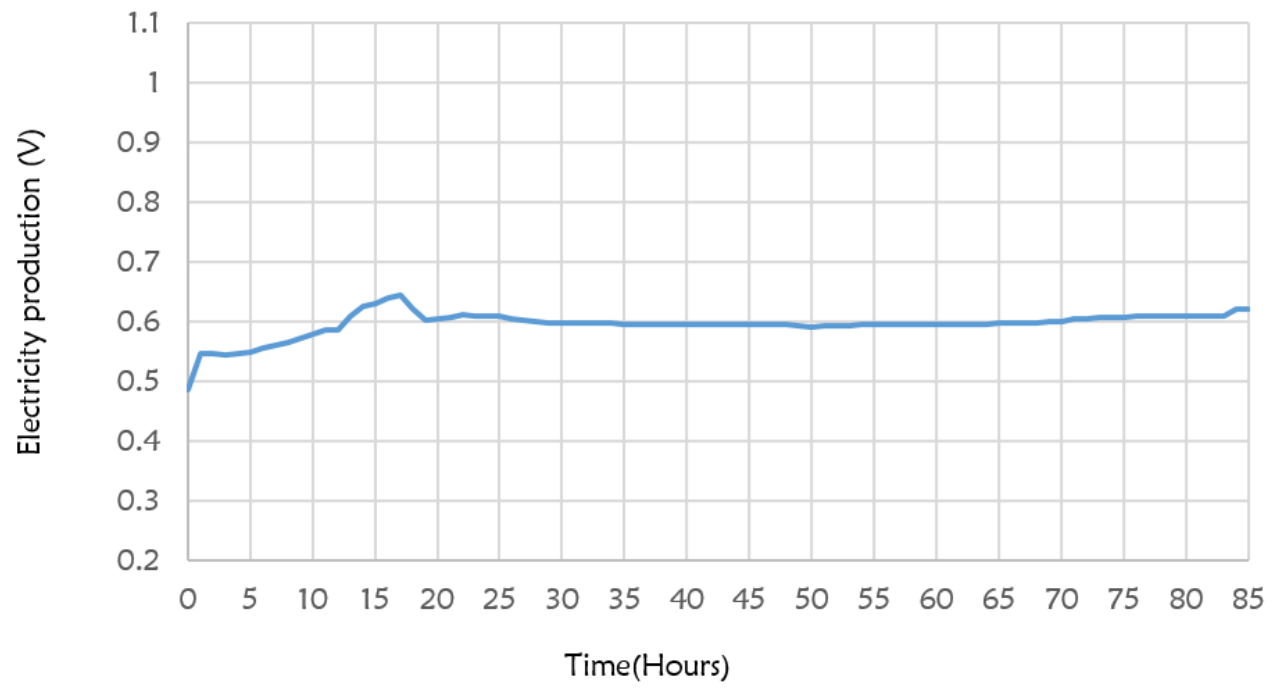

Figure 15: Electricity production versus time for Dyeing waste water-2

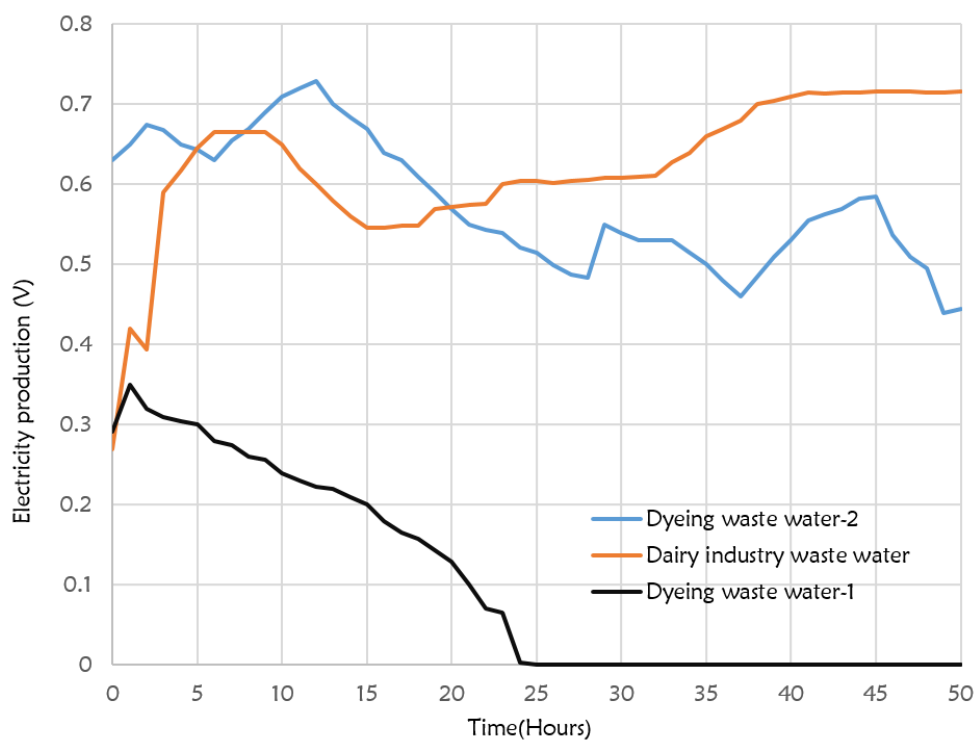

Figure 16: Comparison between the open circuit voltages when using DWW-1, DIWN and DWN-2 (1)

\subsection{Cow Dung}

This observation was done with carbon electrode of round shape just like a rod. In this case the maximum voltage was found as $0.14 \mathrm{~V}$ with current $0.2 \mathrm{~mA}$ which is huge with the same setup arrangement, but the voltage produced was not stable. The initial voltage was $0.1 \mathrm{~V}$ and the voltage increased gradually up to 2 hours. After that the voltage was stable for next 3 hours. Then the voltage decreased gradually for 9 hours. Again it was starts to increase gradually for remaining hours. But the graph shows that the voltage was nearly stable with respect to time. Carbon clothe gives the more stable voltage but expensive than others and that is why it cannot be used in MFC economically. 
Table 9: Electricity production from Cow Dung with respect to time

\begin{tabular}{cccccc}
\hline $\begin{array}{c}\text { Time } \\
\text { (Hours) }\end{array}$ & $\begin{array}{c}\text { Electricity } \\
\text { production }(V)\end{array}$ & $\begin{array}{c}\text { Time } \\
\text { (Hours) }\end{array}$ & $\begin{array}{c}\text { Electricity } \\
\text { production } \\
(\mathrm{V})\end{array}$ & $\begin{array}{c}\text { Time } \\
\text { (Hours) }\end{array}$ & $\begin{array}{c}\text { Electricity } \\
\text { production }(\mathrm{V})\end{array}$ \\
\hline 0 & 0.1 & 10 & 0.113 & 20 & 0.125 \\
1 & 0.11 & 11 & 0.11 & 21 & 0.127 \\
2 & 0.121 & 12 & 0.107 & 22 & 0.128 \\
3 & 0.122 & 13 & 0.105 & 23 & 0.129 \\
4 & 0.122 & 14 & 0.104 & 24 & 0.131 \\
5 & 0.122 & 15 & 0.107 & 25 & 0.132 \\
6 & 0.119 & 16 & 0.116 & 26 & 0.135 \\
7 & 0.118 & 17 & 0.114 & 27 & 0.138 \\
8 & 0.116 & 18 & 0.12 & 28 & 0.14 (Max.) \\
9 & 0.114 & 19 & 0.122 & & \\
\hline
\end{tabular}

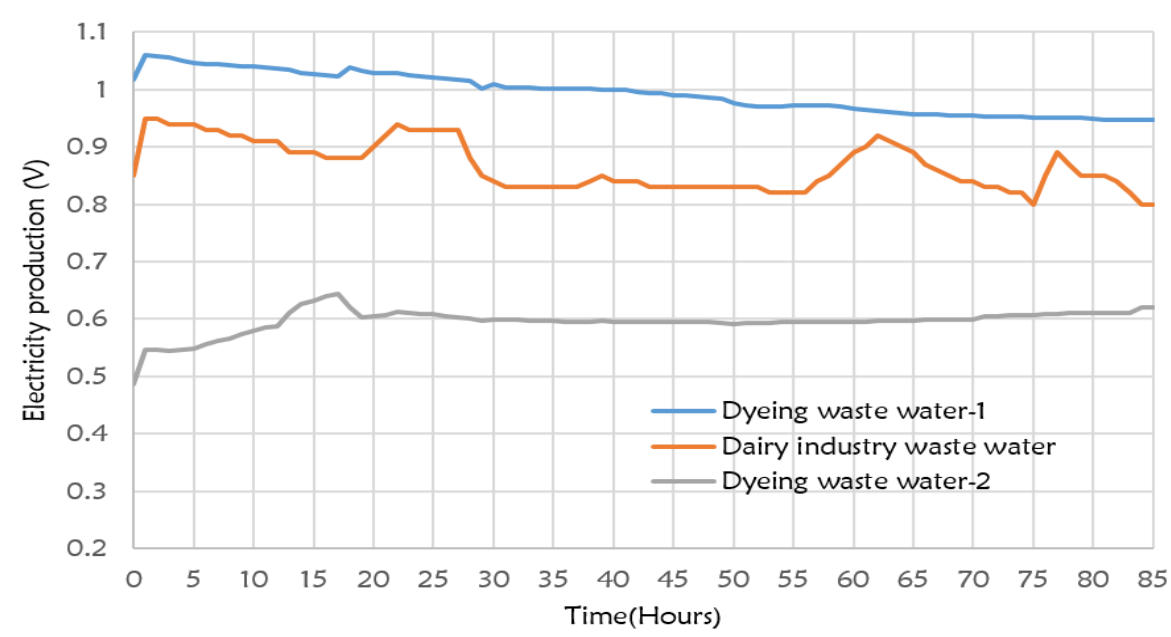

Figure 17: Comparison between the open circuit voltages when using DWN-1, DIWNW and DWN-2 (2)

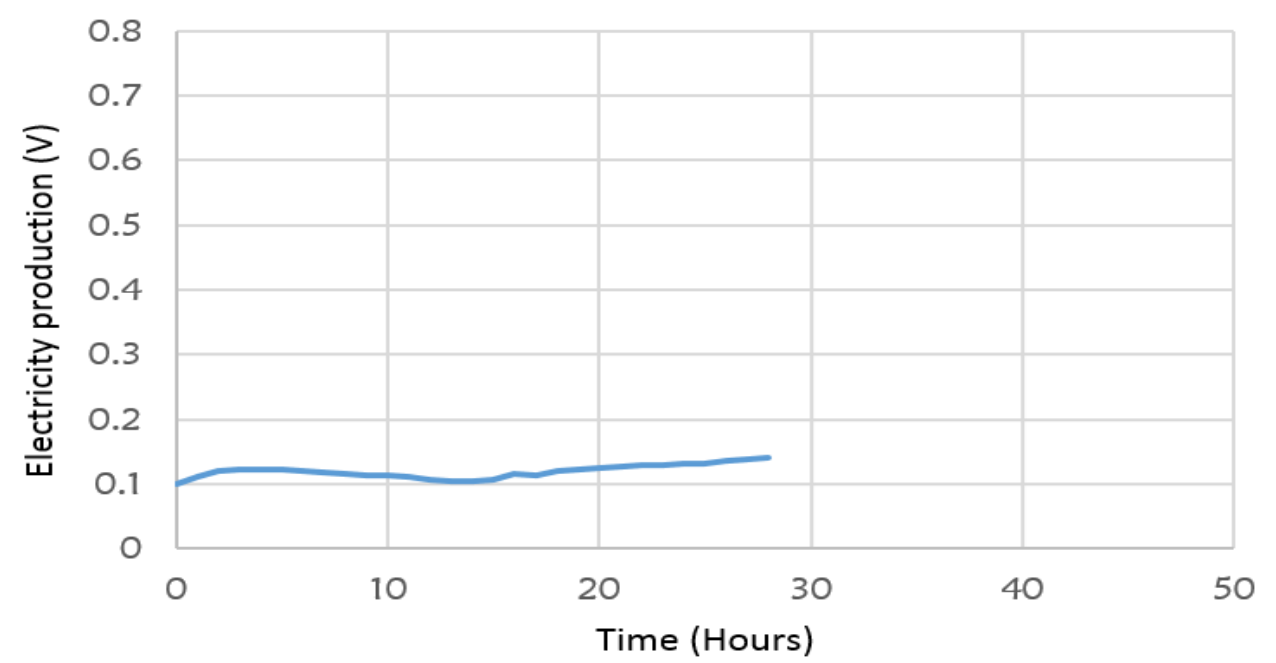

Figure 18: Electricity production versus time for Cow Dung (Carbon Electrode)

\section{CONCLUSION}

In this research, the performance of MFC by using different source of microorganism has been investigated. In the present investigation Dyeing Waste Water-1 (DWN-1), Dairy Industry Waste Water (DIWN), Dyeing Waste Water2 (DWN-2), and Cow Dung were used as source of microorganism. The Copper, Aluminium, Brass and Carbon were used as electrode. Based on the experimental study, the main finding of the study can be summarized as follows:

1. In case of Dyeing waste water-1 (DWW-1), almost stable and maximum voltage was observed till 85 hours. The starting voltage, maximum voltage and current were found $1.017 \mathrm{~V}, 1.06 \mathrm{~V}$ and $07 \mathrm{~mA}$, respectively. An aluminium, brass and copper were used as anode, cathode and electrode in single PEM. 
2. When copper electrodes were used for both anode and cathode side DIWW gave the satisfactory result. In this case initial and maximum voltage was observed $0.27 \mathrm{~V}$ and $0.71 \mathrm{~V}$. But when aluminium was used as anode and brass used as cathode it gave maximum $0.95 \mathrm{~V}$ for 85 hours.

3. An aluminium as anode and brass as cathode gave maximum voltage for samples because the brass is the best conductor of electron and can accumulate proton more efficiently than copper, aluminium and carbon.

It was concluded that for better performance of MFC, selection of source of microorganism and electrode materials are important. For further research, Electrode material can be modified by doping, coating and heat treatment for better performance of MFC. It is remarkable that, microorganism of different substrate can be increased by using different types of catalyst.

\section{REFERENCES}

[1] Lu N, Zhou S, Zhuang L, Zhang J and Ni J 2009 Electricity generation from starch processing wastewater using microbial fuel cell technology, Biochemical Engineering Journal, $43246-51$

[2] Choudhury P, Prasad Uday U S, Bandyopadhyay T K, Ray R N and Bhunia B 2017 Performance improvement of microbial fuel cell (MFC) using suitable electrode and Bioengineered organisms: A review Bioengineered 8 471-87

[3] Kumar R, Singh L, Zularisam A W and Hai F I 2017 Microbial fuel cell is emerging as a versatile technology : a review on its possible applications, challenges and strategies to improve the performances. Int J of Engergy Res, 42(2), 369-394

[4] Guo K, Hassett D J and Gu T 2012 Microbial Fuel Cells: Electricity Generation from Organic Wastes by Microbes, Ch9, 162-189

[5] Chaturvedi V and Verma P 2016 Microbial fuel cell : a green approach for the utilization of waste for the generation of bioelectricity Bioresour. Bioprocess. 3(1), 1-14

[6] Mohan S V, Saravanan R, Raghavulu S V, Mohanakrishna G and Sarma P N 2008 Bioelectricity production from wastewater treatment in dual chambered microbial fuel cell ( MFC) using selectively enriched mixed microflora: Effect of catholyte 99(3) 596-603

[7] Moon H, Chang IS and Kim B H 2006 Continuous electricity production from artificial wastewater using a mediator-less microbial fuel cell. Bioresource Technol, 97 621-627

[8] Scott K and Shukla A K 2004 Polymer electrolyte membrane fuel cells: Principles and advances. Rev Environ Sc Bio/Tech, 3(3) 273-80

[9] Huang L and Logan B E 2008 Electricity generation and treatment of paper recycling wastewater using a microbial fuel cell Appl. Microbiol. Biotechnol. 80 349-55

[10] Gude V G 2018 Microbial Fuel Cells for Wastewater Treatment and Energy Generation Wastewater treatment in microbial fuel cells e an overview J. Clean. Prod. 122 287-307

[11] Duteanu N M, Ghangrekar M M, Erable B and Scott K 2010 Microbial Fuel Cells - An option for wastewater treatment Environ. Eng. Manag. J. 9 1069-87

[12] Li J 2013 An experimental study of microbial fuel cell for electricity generating: performance characterisation and capacity improvement, J Sust Bio Energy, 3(3), 171-178

[13] Logan B E, Hamelers B, Rozendal R, Schröder U, Keller J, Freguia S, Aelterman P, Verstraete W and Rabaey K 2006 Microbial fuel cells: Methodology and technology Environ. Sci. Technol. 40 5181-92

[14] Tharali A D, Sain N and Osborne WJ 2016 Microbial fuel cells in bioelectricity production Front. Life Sci. 9 252-66

[15] Bhargavi G, Venu V and Renganathan S 2018 Microbial fuel cells: Recent developments in design and materials IOP Conf. Ser. Mater. Sci. Eng. 330

[16] Mustakeem 2015 Electrode materials for microbial fuel cells: Nanomaterial approach Mater. Renew. Sustain. Energy 4 1-11

[17] Mashkour M and Rahimnejad M 2015 Effect of various carbon-based cathode electrodes on the performance of microbial fuel cell Biofuel Res. J. 2 296-300

[18] Santoro C, Arbizzani C, Erable B and leropoulos I 2017 Microbial fuel cells: From fundamentals to applications. A review J. Power Sources 356 225-44

[19] Hamed M S, Majdi H S and Hasan B O 2020 Effect of Electrode Material and Hydrodynamics on the Produced Current in Double Chamber Microbial Fuel Cells ACS Omega 5 10339-10348

[20] Palanisamy G, Jung H Y, Sadhasivam T, Kurkuri M D, Kim S C and Roh S H 2019 A comprehensive review on microbial fuel cell technologies: Processes, utilization, and advanced developments in electrodes and membranes J. Clean. Prod. 221 598-621

[21] Prasad J G and Panda S 2018 Microbial Fuel Cells: Types of MFC and Different Source of Substrate. IntJ Latest Technol Eng Mgt App Sc, VII 158-65

[22] Bohari Z H, Azhari N A, Rahman N N A, Baharom M F, Jali M H, Sulaima M F and Izzuddin T A 2017 Experimental study of bioelectricity-microbial fuel cell for electricity generation: Performance characterization and capacity improvement J. Teknol. 79 1-5 